\title{
TRANSPORT OF PARTICULATE MATTER THROUGH THE HUMAN FEMALE GENITAL TRACT
}

\author{
C. H. DE BOER \\ Women's Hospital, Liverpool
}

(Received 11th August 1971, accepted 3rd September 1971)

\begin{abstract}
Summary. A small quantity of India ink placed in the uterine cavity before laparotomy was found to have been transferred to the Fallopian tubes in more than $50 \%$ of the observed patients. Transfer from the cervical canal occurred in nearly $30 \%$ of patients but transfer from the vagina occurred only once in thirty-seven observations. The influence of the phase of the menstrual cycle, the use of Syntocinon and the state of the Fallopian tubes is considered.
\end{abstract}

Rowson (1955) showed that radio-opaque material introduced into the cervix of the cow at artificial insemination was spread rapidly throughout the whole of the uterine horn; at oestrus, the spread extended into the Fallopian tube but, during the luteal phase, it was limited to the horn. The rate of transport of spermatozoa in the cow has been shown to be influenced by oxytocin. (VanDemark \& Moeller, 1951). In the human subject, Egli \& Newton (1961) found that carbon particles passed from the vagina to the Fallopian tubes within a few minutes of placement in two out of three patients.

A quantity of India ink (a collodial suspension of carbon) was placed at a selected level in the genital tract of a number of patients about to undergo an abdominal surgical procedure. Some received an intramuscular injection of 2 units Syntocinon at the same time. At operation $15 \mathrm{~min}$ to $24 \mathrm{hr}$ later, the Fallopian tubes were examined macroscopically and the presence or absence of black material was recorded. A total of 178 operations was performed, 135 of these were for abdominal tubal ligation, twenty-eight for hysterectomy-in one, oophorectomy was performed-and fourteen were for tubal diathermy under a laparoscopic technique. The results of the study are shown in Table 1.

In the majority of the positive cases, there was no doubt that the carbon particles were present in the Fallopian tubes. In some, there had been spill into the peritoneal cavity in quantities sufficient to require swabbing out. In the tube itself, the carbon suspension frequently seemed to be held in short segments, giving the tube a beaded appearance.

Injection of the India ink into the uterus rarely caused difficulty and was made without any force. Injection into the cervical canal was often difficult, with immediate flow back into the vagina and it is possible that some of the injected material reached the uterine cavity directly. The findings after cervical injection must accordingly be suspect.

From the uterine cavity, transport of the India ink to the Fallopian tubes was 
slightly more frequent in the secretory phase $(64 \%)$ than in the proliferative phase $(54 \%)$. From the cervix, this finding was reversed; $22 \%$ in the secretory phase, and $33 \%$ in the proliferative phase.

Syntocinon had little effect on the outcome. Considering both levels of the uterus together, there were $48 \%$ of positives in the Syntocinon-treated group and $47 \%$ in the untreated group.

TABLE 1

TRANSPORT OF INDIA INK TO THE FALLOPIAN TUBES FOLLOWING DEPOSITION INTO THE GENITAL TRAGT

\begin{tabular}{|c|c|c|c|c|c|c|c|}
\hline \multicolumn{3}{|c|}{ Treatment } & All cases & $\begin{array}{c}\text { With } \\
\text { Syntocinon }\end{array}$ & $\begin{array}{c}\text { Without } \\
\text { Syntocinon }\end{array}$ & $\begin{array}{l}\text { Within } 30 \text { min } \\
\text { of injection }\end{array}$ & $\begin{array}{l}\text { Within } 60 \mathrm{~min} \\
\text { of iniection }\end{array}$ \\
\hline \multirow[t]{3}{*}{ I. } & $\begin{array}{l}\text { Injection of } 0.2 \\
\text { ml ink into } \\
\text { uterine cavity }\end{array}$ & & & & & & \\
\hline & $\begin{array}{l}\text { A. Proliferative } \\
\text { phase of cycle }\end{array}$ & $\begin{array}{l}\text { Positive } \\
\text { Negative }\end{array}$ & $\begin{array}{c}27(54 \%) \\
23\end{array}$ & $\begin{array}{l}7 \\
5\end{array}$ & $\begin{array}{l}20 \\
18\end{array}$ & $\begin{array}{l}2 \\
3\end{array}$ & $\begin{array}{l}6 \\
5\end{array}$ \\
\hline & $\begin{array}{l}\text { B. Secretory } \\
\text { phase of cycle }\end{array}$ & $\begin{array}{l}\text { Positive } \\
\text { Negative }\end{array}$ & $\begin{array}{c}23(64 \%) \\
12\end{array}$ & $\begin{array}{l}3 \\
4\end{array}$ & $\begin{array}{r}20 \\
8\end{array}$ & $\begin{array}{l}3 \\
2\end{array}$ & $\begin{array}{l}7 \\
2\end{array}$ \\
\hline \multirow[t]{5}{*}{ II. } & $\begin{array}{l}\text { Injection of } 0.2 \\
\text { ml ink into } \\
\text { cervical canal }\end{array}$ & & & & & & \\
\hline & $\begin{array}{l}\text { A. Proliferative } \\
\text { phase of cycle }\end{array}$ & $\begin{array}{l}\text { Positive } \\
\text { Negative }\end{array}$ & $\begin{array}{c}11(33 \%) \\
22\end{array}$ & $\begin{array}{l}3 \\
4\end{array}$ & $\begin{array}{r}8 \\
18\end{array}$ & - & - \\
\hline & $\begin{array}{l}\text { B. Secretory } \\
\text { phase of cycle }\end{array}$ & $\begin{array}{l}\text { Positive } \\
\text { Negative }\end{array}$ & $\begin{array}{c}4(22 \%) \\
14\end{array}$ & $\begin{array}{l}1 \\
2\end{array}$ & $\begin{array}{r}3 \\
12\end{array}$ & - & - \\
\hline & $\begin{array}{l}\text { C. Post meno- } \\
\text { pause }\end{array}$ & $\begin{array}{l}\text { Positive } \\
\text { Negative }\end{array}$ & $\begin{array}{l}1 \\
3\end{array}$ & 二 & $\overline{-}$ & - & 二 \\
\hline & D. Post abortion & $\begin{array}{l}\text { Positive } \\
\text { Negative }\end{array}$ & $\begin{array}{l}1 \\
0\end{array}$ & - & - & - & $=$ \\
\hline \multicolumn{3}{|c|}{$\begin{array}{l}\text { III. Deposition of } 2 \\
\text { ml ink into } \\
\text { vagina (12 to } 24 \\
\text { hr before } \\
\text { operation) }\end{array}$} & & & & & \\
\hline & $\begin{array}{l}\text { A. Proliferative } \\
\text { phase of cycle }\end{array}$ & $\begin{array}{l}\text { Positive } \\
\text { Negative }\end{array}$ & $\begin{array}{r}1 \\
17\end{array}$ & $\overline{14}$ & $\begin{array}{l}1 \\
3\end{array}$ & - & - \\
\hline & $\begin{array}{l}\text { B. Secretory } \\
\text { phase of cycle }\end{array}$ & $\begin{array}{l}\text { Positive } \\
\text { Negative }\end{array}$ & $\begin{array}{l}0^{*} \\
0\end{array}$ & $\begin{array}{l}19 \\
19\end{array}$ & 二 & - & - \\
\hline
\end{tabular}

Positive - carbon particles present. Negative-no carbon particles present.

* In one of these cases, where hysterectomy was performed, carbon particles were found in the uterus.

In one patient, subsequent histology revealed gross chronic inflammation of the Fallopian tubes. In this patient, a large amount of the carbon suspension was present in the tube. Fox \& Fox (1967) and de Carteret (1967) have suggested that the human female orgasm assists sperm transport by drawing the spermatozoa up into the uterus by suction. This is denied by Masters \& Johnson (1966). Since many fertile women fail to experience an orgasm, it is tempting to consider that the motility of the spermatozoon is purposive. There is no evidence of any chemotactic response by spermatozoa other than their particular mobility in the thin mucus of the oestrogenized cervix. Mattner (1963) considers 
that the effective direction of travel of motile spermatozoa depends on their relative concentrations at either end of the passage under consideration. This may be regarded as a process of accelerated diffusion, the purpose of the sperm motility being to prevent sedimentation.

In the investigation described, there was no doubt that the inert carbon material was frequently and rapidly transported from the uterus to the tubes in both phases of the menstrual cycle. From the vagina to the uterus, passage of the marker was observed only twice in thirty-seven investigations. This is in contrast to the findings of Egli \& Newton (1961), who found two positives out of of three, but the difference may be due to the fact that in the series described here the patients were placed in the Trendelenberg position after the abdomen had been opened. In this position, and especially under anaesthesia, there is a negative intra-abdominal pressure which may be sufficient to draw up material from the vagina into the uterus, particularly through a relaxed cervix. The one positive in this group was a woman who had had six children and had a lacerated cervix.

It is suggested that in man the motility of the spermatozoa is a major factor in overcoming the cervical barrier. Above the level of the cervix, the activity of the upper genital tract, including the Fallopian tubes, ensures the rapid dispersion of any material throughout its whole length. This can occur even when the Fallopian tubes are chronically inflamed.

I would like to express my thanks to Dr R. Rewell, pathologist, for his help and to my Ward Sister, Miss M. Connah, for her patience and co-operation.

\section{REFERENCES}

DE Garteret, R. (1967) Uterine suction during orgasm. Br. med. F. i, 761.

EGLI, G. E. \& NewTon, M. (1961) The transport of carbon particles in the human female reproductive tract. Fert. Steril. 12, 151.

Fox, C. \& Fox, B. (1967) Uterine suction during orgasm. Br. med. 7. i, 300.

Masters, W. \& Johnson, W. (1966) Uterine response to sperm migration. In: Human Sexual Response, Chap. 8, p. 122. Churchill, London.

Mattner, P. E. (1963) Spermatazoa in the genital tract of the ewe. Aust. F. biol. Sci. 16, 877.

Rowson, L. E. A. (1955) The movement of radio opaque material in the bovine uterine tract. Br. vet. 7. 3, 334.

VANDemark N. L. B. \& Moeller, A. N. (1951) Spread of spermatozoan transport in reproductive tract of oestrus cow. Am. J. Physiol. 165, 674 . 